\title{
Evolution of osteoarticular disorders as a function of past heavy physical work factors: longitudinal analysis of 627 retired subjects living in the Paris area
}

\author{
Francis Derriennic, Yuriko Iwatsubo, Christine Monfort, Bernard Cassou
}

\begin{abstract}
The relations between osteoarticular disorders and occupational exposure to heavy physical work factors were studied in a random sample of retired subjects living in the Paris area, all of whom had contributed to the same retirement pension fund. 627 subjects were originally seen in 1982-3 and 464 of them were seen again five years later. On both occasions, the same questionnaire was completed during a home interview. Osteoarticular disorders were evaluated by the presence of pain, with or without restricted joint movement, for at least six months before interview. The heavy physical work factors were those reported by the subject at the first interview, and only subjects who stated that they had been exposed to these factors for more than 10 years were considered as exposed persons. For those who were seen twice, the frequency of osteoarticular pain increased during the five years between the two interviews, from $52 \%$ to $65 \%$ in the men and $72 \%$ to $82 \%$ in the women. Among both sexes, these frequencies were significantly higher in those who stated that in the past they had to carry heavy weights and work in tiring positions. The increases in frequency of pain during the five year study period were also related to these occupational factors. In general, the frequencies for subjects not exposed to occupational factors caught up with those found for the exposed group. This interaction of age with the relation between exposure to heavy physical work factors and osteoarticular disorders does not seem to be explained by confounding factors, including age at the first interview, the fact of living alone, of being a former
\end{abstract}

INSERM U 170, 16 avenue Paul Vaillant Couturier, F-94807 Villejuif Cédex, France

F Derriennic, Y Iwatsubo, C Monfort

Centre de Gérontologie, Hôpital Sainte Périne, 49 rue Mirabeau, F-75016 Paris, France

B Cassou manual worker, of having a cardiorespiratory disorder, and smoking habits. The results of the survey suggest that working conditions are an important cause of osteoarticular disorders that last well beyond the end of working life.

(British fournal of Industrial Medicine 1993;50:851-860)

Osteoarticular disorders constitute one of the main forms of health impairment in elderly people. ${ }^{12}$ They are due to various causes that are rheumatic in most cases, but sometimes traumatic and they may be in any of the joints. ${ }^{3}$ The chief expressions of these disorders are pain, which is often chronic, and restricted joint movement in severe cases. ${ }^{4}$

These organic manifestations affect the daily lives of those concerned by limiting their ability to walk, dress and feed themselves, and perform the movements required by other basic functions. ${ }^{5}$ Moreover it is these effects, classified in terms of disability, ${ }^{6}$ which have been most often studied, because of their high prevalence and the requirement to evaluate the needs of the elderly within the framework of public health policies. ${ }^{7}$

On the other hand, much less research has been devoted to osteoarticular risk factors, particularly occupational factors. This is partly attributable to the methodological difficulties involved in relations with, on the one hand, exposure to occupational or other factors and on the other, health disorders that only become evident long after the initial exposure, ${ }^{8}$ at least in a way that can be quantitatively measured in population samples. Also, the various forms of osteoarticular deterioration constitute one of the manifestations of physiological ageing processes and are difficult to study on the basis of cross sectional epidemiological studies. ${ }^{9}$

Among the risk factors concerned, occupational exposure, particularly heavy physical work factors, which often affect all or much of a person's working life, ${ }^{10}$ are often overlooked when the aetiology of health impairments in elderly people is considered.

For all these reasons, a prospective longitudinal survey was conducted in France among retired 
subjects in the Paris area, with the dual purpose of evaluating the evolution of the major organic disorders, especially osteoarticular problems, and of exploring the possible effect of past occupational exposure on this evolution. An earlier cross sectional study conducted at the end of our initial survey ${ }^{11}$ showed that in men, carrying heavy weights in the past was related to an increase in the frequency of osteoarticular disorders. The present study deals with the evolution of these disorders after a follow up of five years.

\section{Population and methods}

The first survey in 1982 and 1983 concerned 320 men and 307 women of the 993 subjects randomly selected from the list of members of a supplementary interprofessional retirement pension fund.

The men and women in the sample had all been employed in, and had settled in, the Paris area after retirement. The survey was conducted with closed ended questionnaires completed during home interviews by specially trained investigators.

In $1987-8$, a second survey was conducted with the same questionnaire under the same conditions among the subjects who had taken part in the first survey. The major trends recorded among this population at the end of the two surveys (table 1) show that about $63 \%$ of the subjects originally selected took part in the first. Of the $84.7 \%$ who were followed up, $74 \%$ were seen and $10.7 \%$ had died. The $15.3 \%$ who were only seen at the first interview were lost to follow up for the prospective study.

All measurements were based on statements by subjects at each interview. The questionnaire was long and comprised 150 main questions. It was drafted so that each question could be easily understood by the subjects without being explained by investigators. On average, the interviews lasted one hour.

The survey method and questionnaire were well accepted by all the subjects. The investigators were not aware of the nature of the relations being explored and believed the purpose of the survey was to describe the general state of health of a group of elderly people as a function of their demographic and social characteristics.

\section{OSTEOARTICULAR DISORDERS}

The two criteria used were based on recommendations by the World Health Organisation (WHO) ${ }^{12}$ : one was the persistence of pain for at least six months before the interview, and the other, the combined presence of pain and restriction of joint movement. The second criterion was designed to test the strength of possible relations between past occupational characteristics and osteoarticular injuries.

The possible presence of pain and restricted joint movement was explored in the questionnaire joint by joint, excluding the temperomandibular joint. A few months after the first interview, 70 voluntary subjects were asked to come for a standardised medical examination at the geriatric consultation centre of the Sainte Périne Hospital in Paris, so that the agreement between subjects' statements at the home interview and clinical investigations could be evaluated. The agreement was good, with Kappa agreement coefficients of 0.64 for pain and 0.59 for restricted joint movement.

\section{OCCUPATIONAL EXPOSURES}

The exposures were identified at the first interview from subjects' answers to a series of closed ended questions included in the home interview. Two types of exposures were considered: environmental factors (noise, heat, dust, bad weather, and toxic substances) and heavy physical work (carrying of heavy weights, work in tiring positions, and vibrations).

For each factor the subjects were considered to have been exposed if they stated that they had been exposed for at least 10 years of their working life.

To appreciate the relevance of the subjects' statements, a group of experts who included specialists in industrial medicine and ergonomics was asked to ascertain the last occupation practised and the one practised for the longest period during their working life for all the male subjects. This was to estimate the possibility of exposure to the mentioned heavy physical work factors. The experts, who were not aware of the statements made by the subjects about their occupational exposure, were asked to say whether they considered such exposure certain, unlikely, or impossible to define.

Table 1 Major study population trends during the five years between interview 1 and interview 2

\begin{tabular}{|c|c|c|c|c|c|}
\hline & \multirow[b]{2}{*}{$\begin{array}{l}\text { Initial sample } \\
\text { No }\end{array}$} & \multirow[b]{2}{*}{$\begin{array}{l}\text { Subjects present at interview } 1 \\
\text { No }\end{array}$} & \multicolumn{3}{|l|}{ Follow up } \\
\hline & & & $\begin{array}{l}\text { Seen again at interview } 2 \\
\text { No (\%) }\end{array}$ & $\begin{array}{l}\text { Deceased } \\
\text { No (\%) }\end{array}$ & $\begin{array}{l}\text { Lost to follow up } \\
\text { No (\%) }\end{array}$ \\
\hline
\end{tabular}

Interview 1, 1982-3; Interview 2, 1987-8. 


\section{CONFOUNDING FACTORS}

Several factors were liable to act as confounders. As subjects' statements about symptoms were earlier found to depend on $\operatorname{sex}^{213}$ all the analyses were done separately for men and women. Age was taken into account by separating the subjects aged 69 years or less at the first interview (the average age on that occasion) from those who were older.

The social factors liable to affect statements of symptoms were expressed as a single dichotomous variable, defined as the socio-occupational category to which the subjects belonged for the longest period of their working lives-that is, a white collar or blue collar category. The first mainly comprised high and medium ranking managerial staff, owners of factories and businesses, and office employees, and the second, foremen, skilled and unskilled workers, and salesmen.

The fact of living alone was also taken into account as an indicator of the social support that Davies considered as a possible risk factor for the health of very elderly subjects, ${ }^{14}$ as were smoking habits, ${ }^{15}$ physical activities, ${ }^{16}$ and obesity, ${ }^{17}$ which have a controversial role in the aetiology of osteoarticular diseases. In this study each confounding factor was defined as a dichotomous variable. Smoking habits discriminated those who had never smoked from the others, physical activities concerned the subjects who stated that they performed non-domestic physical activities alone or in groups, and the subjects were classified as obese if their body mass index $\left(\mathrm{kg} / \mathrm{m}^{2}\right)$ was greater than the mean plus standard deviation of the body mass index in the sample for each sex.

The subjects' general state of health can also affect their statements, and osteoarticular disorder is of course one of the components of their health.
Therefore, to avoid creating overadjustment in this respect, only the cardiorespiratory symptoms mentioned in the questionnaire and grouped into a single variable called "cardiorespiratory impairment"11 were considered as an adjustment variable for health. As previous analyses had shown that this variable was strongly linked to the mortality recorded during the study period, it allowed the subjects in the poorest health to be distinguished from the others.

The fact that $15 \%$ of the subjects could not be interviewed twice was a source of potential bias. Comparisons between the subjects followed up and those lost were therefore systematically founded on the basic indices evaluated at the first interview.

\section{STATISTICAL METHODS}

Statistical calculations were done with SAS software. Qualitative adjustment methods were derived from the Mantel-Haenzel procedures. Bilateral tests with a threshold of $5 \%$ or less were considered significant.

\section{Results}

NATURE OF THE SAMPLE AND OCCUPATION IN THE LONGITUDINAL FOLLOW UP

Table 2 shows that the 219 male subjects seen at both interviews had an average age of 68.4 (SD 3.3 ) years at the first interview and the 245 female subjects an average age of 68.5 (SD 3.4 ) years. The average age at retirement was 63.0 years for the men and 63.4 years for the women. The survey began when an average of six years had elapsed since retirement. For both men and women, there were only small differences for average age at the first interview and average age at retirement

Table 2 Main sociodemographic characteristics of the study population according to follow up

\begin{tabular}{|c|c|c|c|c|c|}
\hline \multirow[b]{2}{*}{ Characteristics } & \multirow{2}{*}{$\begin{array}{l}\text { Subjects } \\
\text { present } \\
\text { at Interview } 1 \\
\text { Interview } 1\end{array}$} & \multirow{2}{*}{$\begin{array}{l}\text { Subjects } \\
\text { deceased } \\
\text { before Interview } 2 \\
\text { Interview } 1\end{array}$} & \multirow{2}{*}{$\begin{array}{l}\text { Subjects lost } \\
\text { to follow up } \\
\text { by Interview } 2 \\
\text { Interview } 1\end{array}$} & \multicolumn{2}{|c|}{$\begin{array}{l}\text { Subjects followed up from } \\
\text { Interview } 1 \text { to Interview } 2\end{array}$} \\
\hline & & & & Interview 1 & Interview 2 \\
\hline $\begin{array}{l}\text { Number of subjects } \\
\text { Mean age (y) at interview (SD) } \\
\text { Mean age (y) at retirement (SD) } \\
\text { Occupational state (\%): }\end{array}$ & $\begin{array}{l}320 \\
68 \cdot 9(4 \cdot 0) \\
62 \cdot 8(4 \cdot 0)\end{array}$ & $\begin{array}{l}55 \quad \text { Men } \\
69 \cdot 0(5 \cdot 5) \\
61.9(3 \cdot 5)\end{array}$ & $\begin{array}{l}46 \\
68 \cdot 2(2 \cdot 7) \\
62 \cdot 7(3 \cdot 5)\end{array}$ & $\begin{array}{r}219 \\
68 \cdot 4(3 \cdot 3)\end{array}$ & $\begin{array}{l}219 \\
73 \cdot 7(3 \cdot 5) \\
(4 \cdot 1)\end{array}$ \\
\hline $\begin{array}{l}\text { Executives } \\
\text { Clerks } \\
\text { Blue collar workers } \\
\text { Others }\end{array}$ & $\begin{array}{r}36 \cdot 9 \\
9 \cdot 7 \\
40 \cdot 9 \\
12 \cdot 5\end{array}$ & $\begin{array}{r}40 \cdot 0 \\
9 \cdot 1 \\
40 \cdot 0 \\
10 \cdot 9\end{array}$ & $\begin{array}{r}28 \cdot 3 \\
6 \cdot 5 \\
39 \cdot 1 \\
26 \cdot 1\end{array}$ & \multicolumn{2}{|c|}{$\begin{array}{l}37 \cdot 9 \\
10 \cdot 5 \\
41 \cdot 6 \\
10 \cdot 0\end{array}$} \\
\hline $\begin{array}{l}\text { Number of subjects } \\
\text { Mean age (y) at interview (SD) } \\
\text { Mean age (y) at retirement (SD) } \\
\text { Occupational state (\%): }\end{array}$ & $\begin{array}{l}307 \\
69 \cdot 1(4 \cdot 0) \\
63 \cdot 2(4 \cdot 8)\end{array}$ & $\begin{array}{l}\quad \text { Women } \\
12 \\
69 \cdot 8(5 \cdot 3) \\
64 \cdot 5(2 \cdot 6)\end{array}$ & $\begin{array}{l}50 \\
68 \cdot 2(3 \cdot 9) \\
61 \cdot 6(4 \cdot 4)\end{array}$ & $\begin{array}{l}245 \\
68.5(3.4)\end{array}$ & $\begin{array}{l}245 \\
73.8(3 \cdot 0) \\
(4 \cdot 9)\end{array}$ \\
\hline $\begin{array}{l}\text { Executives } \\
\text { Clerks } \\
\text { Blue collar workers } \\
\text { Others }\end{array}$ & $\begin{array}{l}16 \cdot 3 \\
36 \cdot 8 \\
30 \cdot 3 \\
16 \cdot 6\end{array}$ & $\begin{array}{r}8 \cdot 3 \\
58 \cdot 3 \\
33 \cdot 3 \\
-\end{array}$ & $\begin{array}{l}10 \cdot 0 \\
32 \cdot 0 \\
42 \cdot 0 \\
16 \cdot 0\end{array}$ & \multicolumn{2}{|c|}{$\begin{array}{l}18 \cdot 0 \\
36 \cdot 7 \\
27 \cdot 8 \\
17 \cdot 5\end{array}$} \\
\hline
\end{tabular}


Table 3 Frequencies of osteoarticular disorders in the study population according to state between interviews 1 and 2

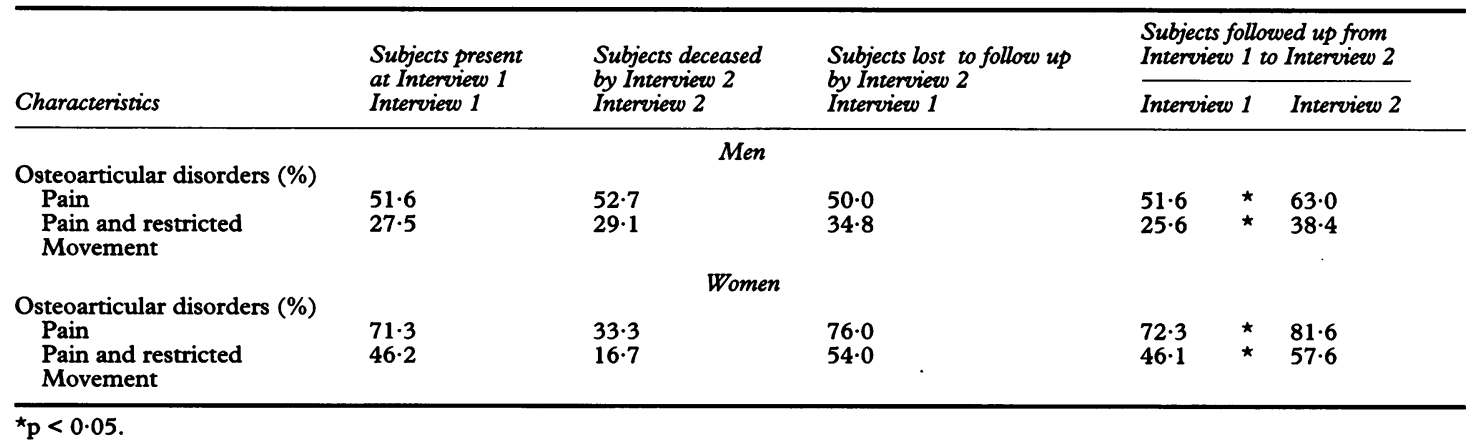

between those who were followed up and those who were lost to follow up.

The results for the longest period in a particular occupation show the mixed occupational nature of members of the pensions fund chosen. In this respect, the $17 \cdot 2 \%$ of the men who died were not different from those who survived. On the other hand, those who were lost to follow up (about 15\% each of men and women) included slightly fewer executives and a few more "other types" of workers and the difference between the socioprofessional distribution of those followed up and those lost was significant for the men. For the women, this group comprised proportionally more blue collar workers and fewer managerial staff than the group of women followed up, but for both groups combined, the difference in socio-occupational distribution was not significant.

\section{FREQUENCY OF OSTEOARTICULAR DISORDERS}

The frequency of osteoarticular disorders was high: among the men, $51.6 \%$ had pain and $27.5 \%$ had restricted joint movement at the first interview. For the women $71 \cdot 3 \%$ had pain and $46 \cdot 2 \%$ restricted

Table 4 foint by joint frequencies (\%) of pain and of pain with restricted movements for men and women, according to state between interviews 1 and 2

\begin{tabular}{|c|c|c|c|c|}
\hline \multirow[b]{2}{*}{ foint } & \multicolumn{2}{|l|}{ Men } & \multicolumn{2}{|l|}{ Women } \\
\hline & $\begin{array}{l}\text { Interview } 1 \\
(n=219)\end{array}$ & Interview 2 & $\begin{array}{l}\text { Interview } 1 \\
(n=245)\end{array}$ & Interview 2 \\
\hline \multicolumn{5}{|l|}{$\begin{array}{l}\text { Upper limbs: } \\
\text { Any localisations: }\end{array}$} \\
\hline $\begin{array}{l}\text { Pain } \\
\text { Restricted movement }\end{array}$ & $\begin{array}{l}28 \cdot 8 \\
11 \cdot 4\end{array}$ & $\begin{array}{l}35 \cdot 6 \\
20 \cdot 5\end{array}$ & $\begin{array}{l}42 \cdot 0 \\
22 \cdot 0\end{array}$ & $\begin{array}{l}55 \cdot 5 \\
32 \cdot 2\end{array}$ \\
\hline \multicolumn{5}{|l|}{ Shoulders: } \\
\hline $\begin{array}{l}\text { Pain } \\
\text { Restricted movement }\end{array}$ & $\begin{array}{r}21 \cdot 9 \\
6.8\end{array}$ & $\begin{array}{l}25 \cdot 6 \\
15 \cdot 5\end{array}$ & $\begin{array}{l}26 \cdot 1 \\
11 \cdot 8\end{array}$ & $\begin{array}{l}35 \cdot 5 \\
21 \cdot 2\end{array}$ \\
\hline \multicolumn{5}{|l|}{ Elbows: } \\
\hline $\begin{array}{l}\text { Pain } \\
\text { Restricted movement }\end{array}$ & $\begin{array}{l}5 \cdot 0 \\
1 \cdot 8\end{array}$ & $\begin{array}{l}8 \cdot 2 \\
4 \cdot 6\end{array}$ & $\begin{array}{l}8 \cdot 2 \\
3 \cdot 3\end{array}$ & $\begin{array}{r}12 \cdot 2 \\
5 \cdot 7\end{array}$ \\
\hline \multicolumn{5}{|l|}{ Wrists: } \\
\hline $\begin{array}{l}\text { Pain } \\
\text { Restricted movement }\end{array}$ & $\begin{array}{l}7 \cdot 3 \\
4 \cdot 6\end{array}$ & $\begin{array}{l}7 \cdot 3 \\
4 \cdot 1\end{array}$ & $\begin{array}{r}15 \cdot 5 \\
8 \cdot 2\end{array}$ & $\begin{array}{l}24 \cdot 5 \\
13 \cdot 5\end{array}$ \\
\hline \multicolumn{5}{|l|}{ Fingers: } \\
\hline $\begin{array}{l}\text { Pain } \\
\text { Restricted movement }\end{array}$ & $\begin{array}{l}7 \cdot 8 \\
3 \cdot 7\end{array}$ & $\begin{array}{r}14 \cdot 6 \\
9 \cdot 1\end{array}$ & $\begin{array}{r}19 \cdot 2 \\
9 \cdot 4\end{array}$ & $\begin{array}{l}26 \cdot 5 \\
13.9\end{array}$ \\
\hline \multicolumn{5}{|l|}{$\begin{array}{l}\text { Spine: } \\
\text { Sptea movement }\end{array}$} \\
\hline $\begin{array}{l}\text { Pain } \\
\text { Restricted movement }\end{array}$ & $\begin{array}{r}21 \cdot 5 \\
8 \cdot 7\end{array}$ & $\begin{array}{l}36 \cdot 5 \\
19 \cdot 6\end{array}$ & $\begin{array}{l}37 \cdot 6 \\
20 \cdot 8\end{array}$ & $\begin{array}{l}54 \cdot 7 \\
34 \cdot 7\end{array}$ \\
\hline \multicolumn{5}{|l|}{$\begin{array}{l}\text { Lower limbs: } \\
\text { Any localisations }\end{array}$} \\
\hline $\begin{array}{l}\text { Pain } \\
\text { Restricted movement }\end{array}$ & $\begin{array}{l}32 \cdot 0 \\
17 \cdot 4\end{array}$ & $\begin{array}{l}36 \cdot 5 \\
21 \cdot 5\end{array}$ & $\begin{array}{l}51 \cdot 8 \\
31 \cdot 8\end{array}$ & $\begin{array}{l}52 \cdot 6 \\
39 \cdot 9\end{array}$ \\
\hline $\begin{array}{l}\text { Hips: } \\
\quad \text { Pain } \\
\text { Restricted movement }\end{array}$ & $\begin{array}{r}14 \cdot 2 \\
7 \cdot 8\end{array}$ & $\begin{array}{l}20 \cdot 1 \\
13 \cdot 2\end{array}$ & $\begin{array}{l}23 \cdot 3 \\
14 \cdot 3\end{array}$ & $\begin{array}{l}26 \cdot 5 \\
18 \cdot 0\end{array}$ \\
\hline $\begin{array}{l}\text { Knees: } \\
\text { Pain } \\
\text { Restricted movement } \\
\text { Ankles: }\end{array}$ & $\begin{array}{r}21 \cdot 0 \\
8 \cdot 7\end{array}$ & $\begin{array}{l}23 \cdot 3 \\
14 \cdot 2\end{array}$ & $\begin{array}{l}38 \cdot 0 \\
22 \cdot 4\end{array}$ & $\begin{array}{l}40 \cdot 4 \\
23 \cdot 7\end{array}$ \\
\hline $\begin{array}{l}\text { Pain } \\
\text { Restricted movement } \\
\text { Mean number of joints affected (SD) }\end{array}$ & $\begin{array}{l}11 \cdot 4 \\
5 \cdot 9 \\
2 \cdot 1(1 \cdot 4)\end{array}$ & $\begin{array}{l}11 \cdot 9 \\
7 \cdot 3 \\
2 \cdot 1(2 \cdot 0)\end{array}$ & $\begin{array}{l}13 \cdot 1 \\
6 \cdot 2 \\
2 \cdot 5(1 \cdot 6)\end{array}$ & $\begin{array}{l}20 \cdot 0 \\
10 \cdot 6 \\
2 \cdot 8(2 \cdot 2)\end{array}$ \\
\hline
\end{tabular}


movement (table 3).

During the five years between the two interviews, both frequencies rose significantly (paired $\chi^{2}$ test). The frequency of pain was increased times 1.2 in the men and 1.1 in the women, and that of joint restriction by 1.5 in the men and 1.2 in the women.

Overall among those who had declared osteoarticular disorders at the first interview, almost $50 \%$ of the men and $60 \%$ of the women had some articular restriction, and at the second, these percentages rose to $60 \%$ and $70 \%$ respectively.

Analysis of data from the first interview showed no significant differences between the subjects seen twice and the others, whether they died or were lost to follow up. The frequencies of pain and restricted movement were greater, however, among the subjects lost to follow up by the second interview.

The results for joints of the upper and lower limbs and spine (table 4) show that among both sexes, in all these regions, both pain and restriction of movement increased in frequency. The joints of the shoulders, knees and spine emerged as the most frequently affected. It were not possible to classify the cervical, dorsal, and lumbar part of the spine separately. When the corresponding joints of the upper and lower limbs were grouped together, the lower limbs were found, at the first interview, to be the most affected. Next came the upper limbs, and then the spine. At the end of follow up, these three main anatomical regions were affected to about the same extent: in about $36 \%$ of the men and $55 \%$ of the women (table 4).

Therefore, during the five year period considered, pain and restriction of movement increased the most for the spine, by $14 \%$ in the men and $17 \%$ in the women for pain, and by 17 and $16 \%$ respectively for restriction of movement. The mean number of joints simultaneously affected and specified in table 4 did not increase significantly between the two interviews.
Those lost to follow up during that time, as well as those of the men who died, did not greatly differ from those followed up. Among the women lost to follow up, the frequencies of pain in the upper limbs and spine were a little higher than in the women interviewed twice.

In view of the absence of disagreement between the respective evolutions of the articulations studied, the relations between the osteoarticular disorders and past occupational exposures were mainly analysed from an overall point of view rather than for each joint, to strengthen the statistical power of the study. An analysis joint by joint did not contradict the relation between past exposure to heavy physical work factors and pain or restriction of movement.

\section{RELATIONS BETWEEN OSTEOARTICULAR DISORDERS} AND PAST OCCUPATIONAL EXPOSURES

The results in table 5 for osteoarticular pain for men and women do not include values for the environmental factors (noise, heat, bad weather, and toxic agents) because no statistically significant figures were found.

The frequency of an osteoarticular pain was always greater in the subjects who reported more than 10 years of a particular form of exposure.

For the men, the pain and exposure relation was significant in cross section at both interviews for carrying heavy weights and at the second interview for tiring positions.

Longitudinally, there was a significant increase in the frequency of osteoarticular pain (paired $\chi^{2}$ test) for subjects who had stated that they were exposed to tiring positions, but also for those who said they were not exposed. The increase in frequency of osteoarticular pain was significant for those who had not been subject to carrying heavy weights and not for the others. Overall there was a significant increase in the frequency of osteoarticular pains for

Table 5 Frequency (\%) of osteoarticular pain in men and women according to past exposure to heavy physical work factors exposure and state between interviews 1 and 2

\begin{tabular}{|c|c|c|c|c|c|c|c|c|c|c|c|c|}
\hline \multirow[b]{4}{*}{ Exposure (E) } & & & \multicolumn{10}{|c|}{ State between interview 1 and interview 2} \\
\hline & \multirow{2}{*}{\multicolumn{2}{|c|}{$\begin{array}{l}\text { Deceased } \\
\text { Interview } 1\end{array}$}} & \multirow{2}{*}{\multicolumn{2}{|c|}{$\begin{array}{l}\text { Lost to follow up } \\
\text { Interview } 1\end{array}$}} & \multicolumn{8}{|c|}{ Followed up } \\
\hline & & & & & \multicolumn{3}{|c|}{ Interview 1} & \multicolumn{3}{|c|}{ Interview 2} & \multicolumn{2}{|c|}{ Paired $\chi^{2}$ tes } \\
\hline & $\overline{E-E+}$ & p Value & $\overline{E-E+}$ & p Value & $\overline{E-}$ & $E+$ & $\overline{p \text { Value }}$ & $\overline{E-}$ & $E+$ & p Value & $\overline{E-}$ & $E+$ \\
\hline $\begin{array}{l}\text { Heavy physical work factors } \\
\text { Awkward postures } \\
\text { Carrying heavy weights } \\
\text { Vibrations }\end{array}$ & $\begin{array}{ll}51 & 58 \\
52 & 57 \\
51 & 63 \\
53 & 50\end{array}$ & $\begin{array}{l}\text { NS } \\
\text { NS } \\
\text { NS } \\
\text { NS }\end{array}$ & $\begin{array}{ll}43 & 73 \\
43 & 78 \\
42 & 80 \\
49 & 67\end{array}$ & $\begin{array}{l}\quad \text { Men } \\
\text { NS } \\
\text { NS } \\
\star \\
\text { NS } \\
\text { Women }\end{array}$ & $\begin{array}{l}49 \\
50 \\
47 \\
50\end{array}$ & $\begin{array}{l}58 \\
56 \\
68 \\
65\end{array}$ & $\begin{array}{l}\text { NS } \\
\text { NS } \\
\text { NS }\end{array}$ & $\begin{array}{l}57 \\
59 \\
59 \\
62\end{array}$ & $\begin{array}{l}75 \\
76 \\
77 \\
75\end{array}$ & $\begin{array}{l}\star \\
\star \\
\star \\
\text { NS }\end{array}$ & $\begin{array}{l}\text { NS } \\
\star \\
\star \\
\star\end{array}$ & $\begin{array}{l}\star \\
\star \\
\text { NSS }\end{array}$ \\
\hline $\begin{array}{l}\text { Heavy physical work factors } \\
\text { Awkward postures } \\
\text { Carrying heavy weights } \\
\text { Vibrations }\end{array}$ & $\begin{array}{l}E= \\
E-\end{array}$ & E & $\begin{array}{ll}77 & 70 \\
78 & 67 \\
76 & -100\end{array}$ & $\begin{array}{l}\text { Women } \\
\text { NS } \\
\text { NS } \\
\text { NS }\end{array}$ & $\begin{array}{l}68 \\
69 \\
71 \\
71\end{array}$ & $\begin{array}{l}87 \\
86 \\
84 \\
92\end{array}$ & $\begin{array}{l}\star \\
\star \\
\text { NS } \\
\text { NS }\end{array}$ & $\begin{array}{l}79 \\
79 \\
80 \\
81\end{array}$ & $\begin{array}{l}91 \\
94 \\
96 \\
92\end{array}$ & $\begin{array}{l}\star \\
\star \\
\star \\
\text { NS }\end{array}$ & $\begin{array}{l}\star \\
\star \\
\star \\
\star\end{array}$ & $\begin{array}{l}\text { NS } \\
\text { NS } \\
\text { NS } \\
\text { NS }\end{array}$ \\
\hline
\end{tabular}

${ }^{\star} \mathrm{p}<0.05 ;-=$ insufficient numbers; $\mathrm{E}+=$ exposed; $\mathrm{E}-=$ non-exposed. 
Table 6 Frequency (\%) of osteoarticular pain with restricted movement for men and women according to past heavy physical work factors and state between interviews 1 and 2

\begin{tabular}{|c|c|c|c|c|c|c|c|c|c|c|}
\hline \multirow[b]{4}{*}{ Exposure (E) } & & & \multicolumn{8}{|c|}{ State between interview 1 and interview 2} \\
\hline & \multirow{2}{*}{\multicolumn{2}{|c|}{$\begin{array}{l}\text { Deceased } \\
\text { Interview } 1\end{array}$}} & \multirow{2}{*}{\multicolumn{2}{|c|}{$\begin{array}{l}\text { Lost to follow up } \\
\text { Interview } 1\end{array}$}} & \multicolumn{6}{|c|}{ Followed up } \\
\hline & & & & & \multicolumn{2}{|c|}{ Interview 1} & \multicolumn{2}{|c|}{ Interview 2} & \multicolumn{2}{|c|}{ Paired $\chi^{2}$ test } \\
\hline & $\overline{E-E+}$ & p Value & $\overline{E-E+}$ & p Value & $\overline{E-E+}$ & $p$ Value & $\overline{E-E+}$ & $\overline{p \text { Value }}$ & $\overline{E-}$ & $E+$ \\
\hline $\begin{array}{l}\text { Heavy physical work factors } \\
\text { Awkward postures } \\
\text { Carrying heavy weights } \\
\text { Vibrations }\end{array}$ & $\begin{array}{ll}28 & 33 \\
29 & 29 \\
30 & 25 \\
29 & 25\end{array}$ & $\begin{array}{l}\text { NS } \\
\text { NS } \\
\text { NS } \\
\text { NS }\end{array}$ & $\begin{array}{ll}29 & 55 \\
30 & 57 \\
28 & 60 \\
33 & 67\end{array}$ & $\begin{array}{l}\text { Men } \\
\text { NS } \\
\text { NS } \\
\star \\
\text { NS } \\
\text { Women }\end{array}$ & $\begin{array}{ll}22 & 33 \\
23 & 35 \\
22 & 41 \\
23 & 50\end{array}$ & $\begin{array}{l}\text { NS } \\
\text { NS } \\
\star\end{array}$ & $\begin{array}{ll}35 & 45 \\
39 & 37 \\
34 & 55 \\
37 & 50\end{array}$ & $\begin{array}{l}\text { NS } \\
\text { NS } \\
\text { NS }\end{array}$ & $\begin{array}{l}\star \\
\star \\
\star \\
\star\end{array}$ & $\begin{array}{l}\text { NS } \\
\text { NS } \\
\text { NS } \\
\text { NS }\end{array}$ \\
\hline $\begin{array}{l}\text { Heavy physical work factors } \\
\text { Awkward postures } \\
\text { Carrying heavy weights } \\
\text { Vibrations }\end{array}$ & $\begin{array}{l}E= \\
E=\end{array}$ & $\begin{array}{l}\overline{-} \\
\bar{E}\end{array}$ & $\begin{array}{ll}52 & 60 \\
54 & 56 \\
53 & -100\end{array}$ & $\begin{array}{l}\text { Women } \\
\text { NS } \\
\text { NS } \\
\frac{\text { NS }}{}\end{array}$ & $\begin{array}{l}4260 \\
4261 \\
4552 \\
4483\end{array}$ & $\stackrel{\star}{\star} \underset{\star}{\star}$ & $\begin{array}{ll}66 & 62 \\
56 & 65 \\
56 & 68 \\
57 & 75\end{array}$ & $\begin{array}{l}\text { NS } \\
\text { NS } \\
\text { NS } \\
\text { NS }\end{array}$ & $\begin{array}{l}\star \\
\star \\
\star \\
\star\end{array}$ & $\begin{array}{l}-\mathrm{NS} \\
\text { NS } \\
\text { NS } \\
\text { NS }\end{array}$ \\
\hline
\end{tabular}

${ }^{\star} \mathrm{p}<0.05 ; \mathrm{E}+=$ exposed; $\mathrm{E}-=$ non-exposed.

subjects who were exposed to at least one heavy physical work factor and not for the non-exposed subjects.

For the women, the cross sectional results were much the same for the frequencies at the two interviews. On the other hand, in terms of evolution, none of the paired $\chi^{2}$ tests was significant in the group of occupationally exposed women, but all these tests were significant for the group of women who said they had not been exposed.

As regards the results in table 5 concerning the frequency of pain at the first interview among the men and women lost to follow up and among those deceased, there were no strong indications of a possible bias in the exposure and osteoarticular pain relation. The frequency of osteoarticular pain was greater in those who had stated that they were exposed than in those who said that they were not exposed.

The results in table 6 show the relation between past occupational exposures and the restrictions of movement reported by the subjects. The frequency of lesions in both men and women was always higher among those who reported exposure for 10 years or more. The cross sectional results for lesions, especially those for the second interview, were not quite the same as the results for pain. Thus at interview 2 , a statistically significant relation between pain and exposure to carrying heavy weights was only found for the men. A reduction in statistical power could explain this result, as fewer subjects reported restriction of movement than articular pain.

We noted that longitudinally the paired $\chi^{2}$ tests were all significant for the men and women who had not reported any past occupational exposure.

\section{ADJUSTMENTS}

For the accurate assessment of the evolution of osteoarticular disorders between the two interviews, and to take account of the fact that disorder can occur or can disappear we analysed the relation between occupational exposure and the state of subjects at interviews 1 and 2 in relation to these lesions. Taking $\mathrm{P}-$ and $\mathrm{P}+$ as the absence and presence of disorders respectively at interview 1 and interview $2(P=$ pain), subjects were classified as $\mathbf{P}-\mathbf{P}-, \mathbf{P}+\mathbf{P}-, \mathbf{P}-\mathbf{P}+$ or $\mathbf{P}+\mathbf{P}+$.

Among both men and women, nearly all the percentages of exposure reported were highest in the $\mathrm{P}+\mathrm{P}+$ category and lowest in the $\mathrm{P}-\mathrm{P}-$ category. Overall exposure percentages, both for pain and restriction of movement, increased similarly in a manner corresponding to the specified grading.

When the crude $\chi^{2}$ test or the $\chi^{2}$ trend was significant, a separate adjustment was made for each variable liable to act as a confounding factornamely, age, living alone, manual worker or not, cardiorespiratory impairment, obesity, and smoking habits.

In taking account of these variables, carrying heavy weights in the past was significantly related, for the men, to the level and to the evolution of the frequency of osteoarticular disorders, evaluated from pain or from restricted joint movement. For tiring positions in the past for the men there was a significant relation with the evolution of osteoarticular pain but not with the evolution of restricted joint movement. Overall, exposure to at least one heavy physical work factor was only significantly related to osteoarticular pain. On the other hand, environmental factors comprising physical or chemical exposure seemed completely unrelated to osteoarticular disorders in the men. For the women, a significant relation was found after adjustment, between each heavy physical work factor and osteoarticular pain. For osteoarticular pain with restricted movement, only one relation was found, with tiring positions in the past and after 
adjustment no significant relationship was found. For women, there was a significant relation only between osteoarticular pain with restricted movement and environmental work factors as a whole.

\section{FREQUENCIES OF OSTEOARTICULAR DISORDERS AT} INTERVIEWS 1 AND 2 AS JUDGED BY THE EXPERTS Among the 219 male subjects who were interviewed twice, the experts gave an opinion in $86 \%$ of the cases concerning the carrying of heavy weights, and $75 \%$ of those concerning work in tiring positions. For the relation between the experts' classifications and subjects' statement, the $\chi^{2}$ test remained significant, with positive Kappa coefficients for each subgroup of subjects with or without osteoarticular disorders at interview 1 or interview 2.

Few subjects in the group considered by the experts as non-exposed stated that they had undergone exposure (less than $3 \%$, whatever the type of exposure). On the other hand, the proportion of subjects who said they had experienced no exposure but whom the experts considered to have been exposed was around $20 \%$, depending on the type of exposure, indicating possible underestimation of exposure by the subjects.

Table 7 gives the frequencies of osteoarticular disorders at the first and second interviews, as derived from the intersection between subjects' statements and the experts' opinions with regard to the carrying of heavy weights and work in tiring positions.

With 0 as non-exposure and 1 as exposure, the sub-group 0 for the subjects and 1 for the experts always exhibited an osteoarticular disorder frequency that was intermediate between the 0,0 and 1,1 groups, but nevertheless nearer to that of the 0,0 than the 1,1 group. When group 0,1 was fused with group 0,0 or 1,1 , the frequency of disorders was always higher for exposed than non-exposed subjects.

It is worth noting that the results were clearer for the second than the first interview-that is, when there was no reason to suspect any bias in subjects'

Table 7 Frequencies of osteoarticular disorders at interview 1 and interview 2 according to the cross classification between subjects' statements and the experts' opinions regarding occupational exposure

\begin{tabular}{|c|c|c|c|}
\hline & \multicolumn{3}{|c|}{ Statement of exposure } \\
\hline . & $\begin{array}{l}\text { Subject : no } \\
\text { Expert : no }\end{array}$ & $\begin{array}{l}\text { Subject : no } \\
\text { Expert: yes }\end{array}$ & $\begin{array}{l}\text { Subject : yes } \\
\text { Expert : yes }\end{array}$ \\
\hline $\begin{array}{l}\text { Osteoarticular disorders (\% } \\
\text { Carrying heavy weights } \\
\text { Awkward postures }\end{array}$ & $\begin{array}{l}\% \text { pain) at in } \\
50 \\
55\end{array}$ & $\begin{array}{l}\text { erview 1: } \\
34 \\
55\end{array}$ & $\begin{array}{l}71 \\
61\end{array}$ \\
\hline $\begin{array}{l}\text { Osteoarticular disorders (\% } \\
\text { Carrying heavy weights } \\
\text { Awkward postures }\end{array}$ & $\begin{array}{l}\text { \% pain) at int } \\
58 \\
54\end{array}$ & $\begin{array}{l}\text { erview 2: } \\
63 \\
63\end{array}$ & $\begin{array}{l}81 \\
71\end{array}$ \\
\hline
\end{tabular}

statements, as the second interview only included questions concerning health.

\section{Discussion}

This study shows the existence of a relation between the occupational exposure reported by subjects at home interviews on the one hand, and on the other, firstly the frequency of osteoarticular disorders after retirement and secondly the evolution of these disorders during a five year longitudinal follow up.

More precisely, exposure to carrying heavy weights for more than 10 years of working life seemed to play a predominant part among the men in causing osteoarticular disorders as evaluated from the pain or from the restriction of joint movement reported by the subjects.

Among the women, past occupational exposure seemed rather to be related to the frequency of osteoarticular pains and seemed less specific, as it involved the combination of carrying heavy weights and work in awkward postures. Nevertheless, these results seem to favour stronger involvement of work in tiring positions, if the postretirement frequency of osteoarticular disorders is considered alone, and not its evolution during follow up.

For vibrations, no significant results were shown, partly because of insufficient power (only 20 subjects said they had been exposed to vibrations for more than 10 years).

These results are strengthened by the emergence of a type of dose-effect relation in which the proportions of exposed subjects were higher among those with an osteoarticular disorder when the disorder was defined as the simultaneous presence of pain and restricted joint movement rather than by the presence of pain alone.

Also, comparison of this relation with the results for past exposure to environmental factors suggests that heavy physical work factors affect osteoarticular disorders in a specific way. Thus among the men, no trend emerged to show that exposure to environmental factors was connected with either pain or pain combined with restriction of joint movement. Among the women, a possible relation between osteoarticular disorders and environmental factors could not be ruled out, but the results differed, depending on whether pain alone was considered, or pain combined with restriction of joint movement. This might be partly explained by the few women exposed, and by the fact that more exposed women than men were subjected to a combination of heavy physical work and environmental factors.

Note, however, that these results concern a random sample of retired persons living in the Paris area whose mean age at the first interview was 69 
years, conditions that raise several questions regarding the validity and interpretation of our findings.

Although the subjects interviewed were chosen from lists of members of an interprofessional retirement pensions fund, all the professions were not represented-for instance, there were no former civil servants. The firms for which the subjects had worked mainly belonged to the sectors concerned with metal transformation, transport, business, and the liberal professions. None of them was living in an institution. Concomitant studies of mortality showed no significant difference, however, between mortality among the general French population and that in our original random sample and among the participants in the study. Therefore health factors related to mortality do not seem to have entailed any special form of selection. Nevertheless, about one third of the $37 \%$ of the sample population that did not participate in the study gave, by means of a telephone interview, various severe illnesses as the cause of refusal. This means that possible participant selection according to health cannot be entirely ruled out on the basis of the variables used in this study. If this were the case, there is reason to believe it would tend to minimise rather than maximise the prevalences and weaken the relations found.

Further, participation in the study was independent of age, sex, and place of residence in the Paris suburbs, three variables known before the study from the pension fund files. Similarly, it was possible to check a few quantitative indices summing up the careers of the subjects, according to whether or not they had taken part in the study. ${ }^{18}$ Thus the mean numbers of firms for which subjects had worked were, for the men, $5 \cdot 7$ among participants and 6.1 among non-participants. For the women, the corresponding numbers were 6.5 and 5.7 . The same checking procedure showed that the mean number of branches of economic activity engaged in by men was 2.8 among participants and 3.1 among non-participants, these figures being respectively 3.4 and 3.4 for the women. Hence, no statistically significant difference was detected between participants for job mobility. The absence of the necessary information from the pension fund files made it impossible to check for possible differences between the two groups, however, for the longest lasting socioprofessional occupational category in the subject's working life.

Those lost to follow up between the two interviews may have introduced a selection bias in the longitudinal study. The characteristics at interview 1 of those lost to follow up but who were alive at the time of interview 2 were always compared with those of the subjects seen at both interviews. No significant difference in this respect was found for the men or women, especially for the frequency of osteoarticular disorders, whatever their localisation. Among those who died, the frequencies of osteoarticular lesions for both men and women at the first interview was no higher than among the survivors, whether or not they were lost to follow up. It therefore seems reasonable to conclude that the selections occasioned by participation in one or other interview or both did not bias the results.

On the other hand, the introduction of differential biases is not impossible in connection with the assessment of statements made at the interviews concerning pain or restricted join movement according to the existence or absence of past occupational exposures, also reported at the interviews. Thus it is conceivable that those who reported an osteoarticular symptom at interview 1 remembered past exposures better than those who did not, a point that could have introduced a bias into the relations between exposures and osteoarticular disorders. Nevertheless, in the light of our verifications of the exposures reported by the subjects by comparison with those considered certain by the experts according to the subject's longest lasting occupation, it seems fairly certain that in the worst case, the relation between exposure to heavy physical work factors and osteoarticular disorders was not significant for interview 1 but remained so for interview 2 . This is of interest, because at the second interview, subjects were not asked about their past occupations and their answers at the second interview are therefore unlikely to have been conditioned by their answers at the first.

We also found in an earlier study ${ }^{11}$ that there was good coherence between on the one hand, the signs and symptoms reported by subjects, including pain and restriction of movement, and on the other, the pathological state at the time of the interview.

Lastly, to strengthen the notion of exposure in this study, subjects were only counted as exposed if as pointed out in the methods section, they stated that an occupational exposure had lasted for more than 10 years.

The statistical relations shown here do not seem to have been significantly affected by the possible confounding factors analysed, past or present smoking, living alone, and exposure to physicochemical factors (noise, heat, bad weather, dust, and toxic agents). Certain factors recognised as possible risks 171920 could not be taken into account, however: they comprised muscular strength, general physical aptitude, complaints of past back pain, and more especially, psychosocial factors. Also, as the study population consisted of retired people, the survey did not include questions about individual appreciations of job content, the degree of job satisfaction, or fatigue after work, suggested in several studies of working populations to 
be especially involved in back pain. ${ }^{21} 22$

Consequently, our results cannot be interpreted causally, the more so as there are, as far as we know, no similar studies carried out long after the end of occupational exposure. This raises some problems-for instance, it is hard to understand why, if carrying heavy loads and working in tiring positions are considered as risk factors for osteoarticular disorders, ${ }^{23}{ }^{24}$ their effects are still felt long after retirement, and perhaps evolve differently, depending on whether or not the subject has been exposed. The simplest explanation is to assume that the possible effects during working life are reflected in chronic osteoarticular lesions that, in the absence of population selection, for instance by mortality, will be more frequent among pensioners with past occupational exposure. The interaction of chronic lesions with advancing age between the first and second interviews can be explained in two ways: our results suggest that the more likely explanation is that the frequency of lesions among those not exposed in the past eventually catches up with the frequency found among those exposed. This catching up process would itself seem to result from lesions that might have appeared earlier in subjects exposed to heavy physical work factors during their working life.

From this point of view, an interaction at the first interview between age and past heavy physical work and osteoarticular disorders would be expected. But this interaction was only suggestive because of the small range of ages in our sample (mean age at interview 1: 69 (SD 4) years and because there were few subjects aged over 69 years who declared that they had been exposed to heavy physical work in the past. Despite the general agreement between the expert opinions regarding occupational exposures and subjects' statements we cannot exclude totally an effect due to an over-reporting of symptoms by those who had stated that they were exposed to heavy physical work factors in the past.

A second explanation cannot be entirely ruled out: there may have been some acceleration of the particular processes involved in osteoarticular ageing, possibly triggered or promoted by occupational exposure factors, and this acceleration would only be statistically detectable long after the periods of occupational exposure.

Our study did not include enough exposed subjects to enable us to be more precise. A third phase now being envisaged should allow us to test the theory that the exposed group eventually catches up with the non-exposed group. On the other hand, to examine the second notion of an acceleration of the osteoarticular aging process, it would be necessary to undertake a study, the starting point of which would be during working life.

In any case, the results of our study seem com- patible with the possibility that occupational osteoarticular disorders interact with osteoarticular ageing processes. The present observation of similar evolutionary patterns in retired men and women for the frequencies of osteoarticular disorders argues in favour of such interaction. Also, even though the most profoundly differentiated increase in the frequency of pain was in the spine, all the articular localisations of pain considered were subject to aggravation of lesions either in terms of pain or of restriction of movement, in both men and women.

These results should encourage the organisation of more ambitious studies with a longer follow up and more precise measurements of occupational exposures and tasks, to establish how health and its evolution after retirement remain dependent on previous working conditions. Osteoarticular disorders constitute one of the main causes of physical disability that condition life expectancy without disabilities. ${ }^{6}$ Future improvements must be attempted by improving health safeguards at younger ages, particularly by better occupational hazard prevention, ${ }^{25}$ which is still one of the best procedures for rectifying several of the modifiable factors involved in the incidence or aggravation of osteoarticular disorders. ${ }^{17}$

1 Ford AB, Folmar SJ, Salmon RB, Medalie JH, Roy AN, Galazka SS. Health and function in the old and very old. f Am Geriatr Soc 1988;36:187-97.

2 Hale WE, Perkins LL, May FE, Marks RG, Stewart RB. Symptom prevalence in the elderly, an evaluation of age, sex, disease, and medication use. $\mathcal{F}$ Am Geriatr Soc 1986; 34:333-40.

3 Kelsey JL, Hochberg MC. Epidemiology of chronic musculoskeletal disorders. Annual Reviews of Public Health 1988;9: 379-401.

4 Genti G. Occupation and osteoarthritis. Baillere's Clinical Rheumatology 1989;3:193-204.

5 Jette AM, Branch LG, Berlin J. Musculoskeletal impairments and physical disablement among the aged. $\mathcal{F}$ Gerontol 1990;45:M203-M208.

6 Robine JM, Colvez A. Espérance de vie sans incapacité et ses composantes: de nouveaux indicateurs pour mesurer l'état de santé et les besoins de la population. Population 1984; 1:27-46.

7 Kramer JS, Yelin EH, Epstein WV. Social and economic impacts of four musculoskeletal conditions. Arthritis and Rheum 1983;26:901-10.

8 Vingard E, Hogstedt C, Alfredson L, Fellenius E, Goldie I, Koster M. Coxarthrosis and physical work load. Scand $\mathcal{f}$ Work Environ Health 1991;17:104-9.

9 King DW. In: Kent B, Butler, RN, eds. Pathology and aging in human and aging research: concepts and techniques Vol 34. New York: Raven Press, 1988.

10 Ayoub MA, Wittels NE. Cumulative trauma disorders. International Reviews of Ergonomics 1989;2:217-72.

11 Derriennic F, Cassou B, Lecuyer G, Amphoux M. Déficience locomotrice et cardio-respiratoire après la retraite en relation avec certaines expositions professionnelles durant la vie active. Rev Epidemiol et Santé Publique, 1987;35:263-73.

12 International Classification of Impairments, Disabilities and Handicaps. A manual of classification relating to the consequences of disease. Geneva: OMS, 1980.

13 Aiach P, Leclerc A, Philippe A. Facteurs de différenciation dans la déclaration de symptômes. Rev Epidemiol Santé Publique, 1981;29:27-44.

14 Davies AM. Epidemiology and the challenge of ageing. Int $f$ Epidemiol 1985;14:9-21. 
15 Leigh JP, Sheetz RM. Prevalence of back-pain among fulltime United States workers. Bri f Ind Med 1989;46:651-7.

16 Aloia JF. Exercise and skeletal health. $\mathcal{F} \mathrm{Am}$ Geriatr Soc 1981;29:104-7.

17 Heliovaara M. Risk factors for low back pain and sciatica Ann Med 1989;21:257-64.

18 Iwatsubo Y, Derriennic F, Cassou B. Relation between job mobility during working life and health after retirement: a cross sectional study of 627 subjects living in the Paris area. Br F Ind Med 1991;48:721-8.

19 Riihimaki H, Wickstrom G, Hanninen K, Luopajarvit T. Predictors of sciatic pain among concrete reinforcement workers and house painters-a five year follow-up. Scand 7 Work Environ Health 1989;15:415-23.

20 Swensson HO, Gunnar B, Andersson J. The relationship of low back pain, work history, work environment and stress, retrospective cross-sectional study of 38- to 64-year old women. Spine 1989;14:517-22.
21 Linton SJ. Risk factors for neck and back pain in a working population in Sweden. Work and Stress 1990;4:41-9.

22 Bergenudd H, Lindgarde F, Nilsson BO, Petersson J. Shoulder pain in middle age: a study of prevalence and relation to occupational work load and psychosocial factors. Clin Orthop 1988;231:234-8.

23 Walsk K, Varnes N, Ossiond C, Styles R, Coggon D. Occupational causes of low back pain. Scand $\mathcal{f}$ Work Environ Health 1989;15:54-9.

24 Riihimaki H. Low back pain, its original risk indicators. Scand $\mathcal{f}$ Work Environ Health 1991;17:81-90.

25 Smith DB. Human factors and aging: an overview of research needs and application opportunities. Hum factors 1990; 32:509-26.

Accepted 19 October 1992

\section{Correspondence and editorials}

The British fournal of Industrial Medicine welcomes correspondence relating to any of the material appearing in the journal. Results from preliminary or small scale studies may also be published in the correspondence column if this seems appropriate. Letters should be not more than 500 words in length and contain a minimum of references. Tables and figures should be kept to an absolute minimum. Letters are accepted on the understanding that they may be subject to editorial revision and shortening.

The journal now also publishes editorials which are normally specially commissioned. The Editor welcomes suggestions regarding suitable topics; those wishing to submit an editorial, however, should do so only after discussion with the Editor. 